\title{
MicroRNAs and long non-coding RNAs: prospects in diagnostics and therapy of cancer
}

\author{
Nina Hauptman and Damjan Glavac \\ Department of Molecular Genetics, Institute of Pathology, Medical Faculty, University of Ljubljana, Slovenia
}

Radiol Oncol 2013; 47(4): 311-318.

Received 15 June 2013

Accepted 20 August 2013

Correspondence to: Prof. Damjan Glavac, Ph.D., Department of Molecular Genetics, Institute of Pathology, Medical Faulty, University of Ljubljana, Korytkova 2, SI-1000 Ljubljana, Slovenia. E-mail: damjan.glavac@mf.uni-lj.si

Disclosure: No potential conflicts of interest were disclosed.

The paper was presented at the $7^{\text {th }}$ Conference of Experimental and Translational Oncology, 20-24 ${ }^{\text {th }}$ April 2013, Portoroz, Slovenia (www.ceto.si) co-organised and supported by COST TD1104 Action (www.electroporation.net).

Background. Non-coding RNAs (ncRNAs) are key regulatory molecules in cellular processes, and are potential biomarkers in many diseases. Currently, microRNAs and long non-coding RNAs are being pursued as diagnostic and prognostic biomarkers, and as therapeutic tools in cancer, since their expression profiling is able to distinguish different cancer types and classify their sub-types.

Conclusions. There are numerous studies confirming involvement of ncRNAs in cancer initiation, development and progression, but have only been recently identified as new diagnostic and prognostic tools. This can be beneficial in future medical cancer treatment options, since ncRNAs are natural antisense interactors included in regulation of many genes connected to survival and proliferation. Research is directed in development of useful markers for diagnosis and prognosis in cancer and in developing new RNA-based cancer therapies, of which some are already in clinical trials.

Key words: microRNAs; long non-coding RNAs; diagnosis; therapy; biomarker

\section{Introduction}

Cancer is one of the leading causes of death in the world, following deaths by cardiovascular and infectious disease. Although cancer is widely researched there is still lack of early detection techniques. For detecting early stage tumors and their precise characterization before and after treatment, biomarkers could be used, which consequently could lower the mortality rate. ${ }^{1}$ Research for suitable biomarkers for diagnosis and prognosis is wide-spread, and lately directed into detection in body fluids. For this purpose extensive research in the field of non-coding RNAs (ncRNAs) is conducted.

RNA used to be considered the messenger between the gene and the protein encoded by this gene. ${ }^{2,3}$ The minority of the transcripts are protein coding $(1.5 \%)$, and the rest used to be referred as "dark matter", now known to be the ncRNA tran- scripts. Recent transcriptional analyses of genome estimate that ncRNA sequences are the most transcribed ones. ${ }^{4,5}$ The group of ncRNAs is quite diverse and complex. It is divided into ribosomal RNAs (rRNAs), transfer RNAs (tRNAs), microRNAs (miRNAs), long non-coding RNAs (lncRNAs), small nucleolar RNAs (snoRNAs), small interfering RNAs (siRNAs), small nuclear RNAs (snRNAs), and piwi-interacting RNAs (piRNAs) (Figure 1). ${ }^{6}$

MicroRNAs (miRNAs) are $\sim 22$ nt long RNA molecules and are involved in post-transcriptional regulation. MiRNAs regulate over 30\% of messenger RNAs (mRNAs), mainly through the negative regulation of gene expression, where miRNA bind to regions of mRNA, blocking the translation or completely degrading mRNAs. ${ }^{7}$ It is established that miRNA are included in cellular differentiation, development, proliferation and apoptosis, where they play an important role. In cancer these pro- 


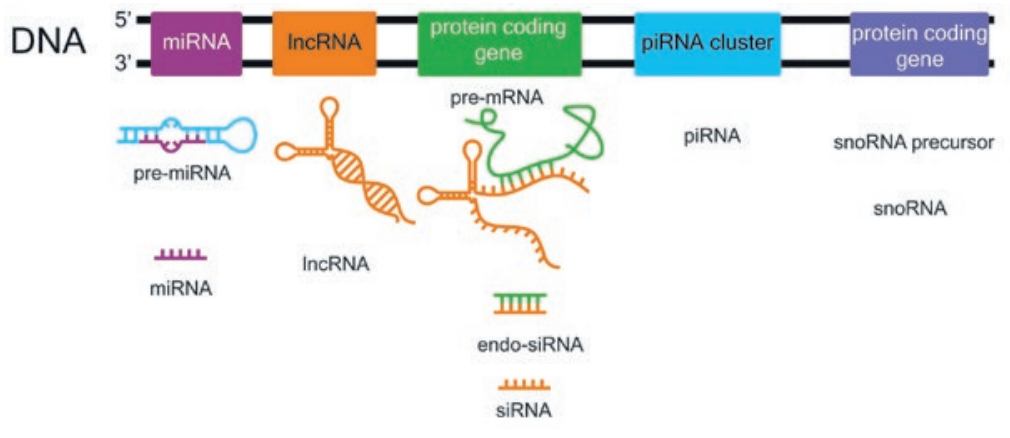

FIGURE 1. Schematic presentation of ncRNAs biogenesis.

cesses are deregulated, meaning that miRNA are involved in carcinogenesis, and could contribute to the initiation and progression of cancer. ${ }^{8}$ Tumor specific miRNA have a potential of becoming cancer biomarkers, since their expression profile can be more specific for determining the classification, diagnosis, and progression in cancer. ${ }^{9}$

LncRNA are classified as over $200 \mathrm{nt}$ long transcripts that lack functionally open reading frame. They are involved in cellular differentiation and proliferation. The mechanisms through which they act are molecular scaffolds, which are involved in transcriptional machinery, as post-transcriptional regulators of splicing or as molecular decoys for miRNA., ${ }^{410}$ The lncRNA research is a new field emerging in molecular genetics, therefore only a small number of lncRNA were characterized. Comparing to miRNA, IncRNA studies are scarcer, nonetheless some promising evidence of using lncRNA as biomarkers for diagnosis and prognosis exist.

PiRNA are a class of regulatory small noncoding RNAs, 23-29 nt in length, which form the piRNA-induced silencing complex in the germ line of many animal species. PiRNA are specifically associated with PIWI proteins, which are germlinespecific members of AGO protein family. The main function of piRNAs is defence against transposable elements in germ cells, and this role is highly conserved across animal species. Transposable elements threaten the genomic integrity of the host. PiRNAs and their interacting proteins have important role in cellular processes, and some of them are potential regulators of cancer cell development. ${ }^{11}$

SnoRNAs are 60-300 nucleotides in length and are predominantly found in nucleus. Their classical function is connected to post-transcriptional modification of ribosomal RNAs and some spliceosomal RNAs. These modifications are necessary for efficient and accurate production of ribosomes. ${ }^{12}$ Modification of ribosome biogenesis has been implicated in cancer development, which indicates
snoRNAs might contribute to cancer, although this area needs further research. ${ }^{12,13}$

SiRNA are usually 19-23 nucleotides in length, which are known to guide silencing of target $\mathrm{mR}$ NA by directing the RNA-induced silencing complex to mediate site-specific cleavage, and destruction of targeted mRNA. ${ }^{14}$ Genes associated with cancer are a potential target of siRNAs, their potential is in inhibition and therapeutics. ${ }^{14-17}$

In this review we will highlight the potential of miRNA and lncRNA for diagnosis and therapy, focusing on specific and sensitive biomarkers and their availability in body fluids. Additionally we will address the therapeutic benefits of miRNA and strategies of delivery to damaged tissues.

\section{Potential in diagnostics}

Biomarkers are biological indicators of disease states, used to classify cancer types or subtypes. ${ }^{18}$ Effective and clinically relevant biomarkers are important for subsequent patient's treatment. ${ }^{19}$ The research on detection of both miRNAs and IncRNAs is orientated toward their detection in body fluids. Comparing to mRNA, the level of expressions of either miRNA or lncRNA may be a better tool for indication of a certain disease. Furthermore, this can be diagnostically applicable when a distinctly specific pattern of expression for a certain disease exists.

One of the reasons of extensive research done on miRNAs connected to cancer is the possibility of conducting research on formalin fixed paraffin embedded (FFPE) samples. Due to their small length, miRNAs are not affected by formalin fixation and degradation over time like longer RNA molecules, such as mRNA and lncRNA, where fresh frozen samples are needed. ${ }^{20-22}$

\section{MiRNA diagnostic}

The most commonly observed miRNA, which is up-regulated in human cancers, is miR-21 (Table 1). Overexpression was observed in breast, lung, prostate and other cancers, where it was shown to increase cell proliferation and invasion, and its suppression led to decrease in the cell proliferation, invasion, and induced apoptosis. ${ }^{23-25}$

Another miRNA up-regulated in breast, lung, pancreatic and other cancers is miR-155, which overexpression is also associated with tumorigenesis in lymphoma..$^{52}$ Also in blood samples these two miRNAs are the most deregulated. Other 
TABLE 1. Potential diagnostic miRNA biomarkers in tissue and blood samples

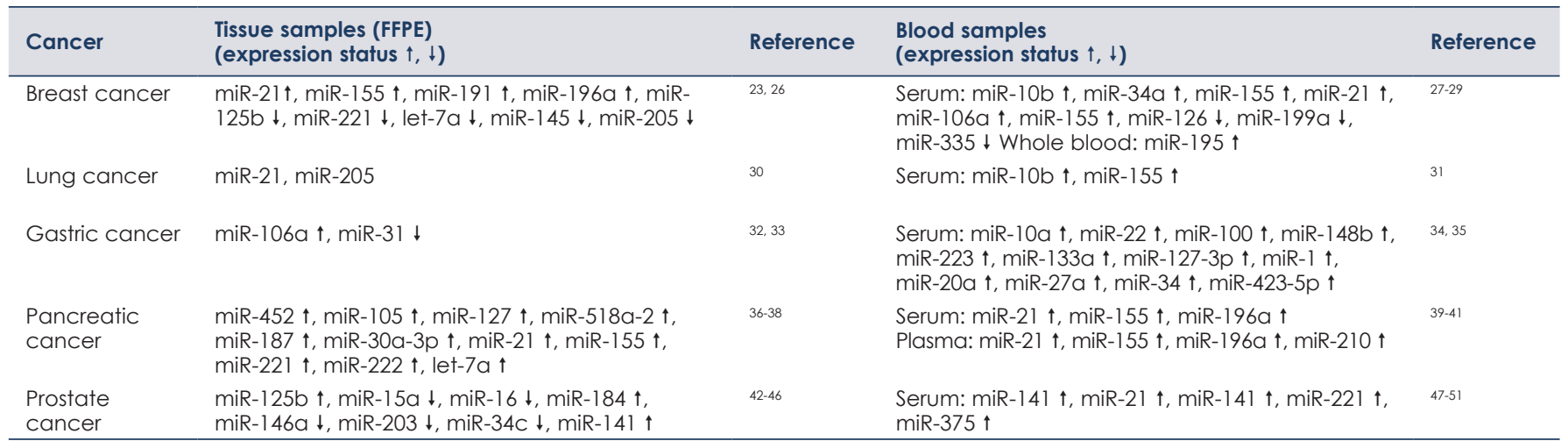

TABLE 2. InCRNA deregulated in cancer

\begin{tabular}{|c|c|c|c|c|}
\hline ANRIL & $\sim 3.9$ & Prostate, leukemia & $\uparrow$ & 58 \\
\hline PRNCR1 & 13 & Prostate & & ${ }^{61}$ \\
\hline H19 & 2.3 & Bladder, lung, liver, breast, esophagus, choriocarcinoma, colorectal cancer & & $62-68$ \\
\hline MALATI & 7.5 & Breast, prostate, colon, liver, uterus & $\uparrow$ & $73-76$ \\
\hline MEG3 & 1.6 & Brain & $\downarrow$ & 77.78 \\
\hline PTNEP1 & 3.9 & Prostate & & 79 \\
\hline Spry4-it1 & $\sim 0.7$ & Melanoma & $\uparrow$ & 80 \\
\hline GAS5 & isoforms & Breast & $\downarrow$ & 86 \\
\hline
\end{tabular}

miRNAs do not overlap in the cancer type groups either in tissue or blood samples. The overlap between the tissue and blood samples of the same cancer type was observed in prostate cancer, where miRNA-141 is expressed in tissue and patients sera, and could differentiate between patients with cancer and healthy controls. ${ }^{51}$ Another example is observed in plasma of patients with colorectal cancer (CRC), where levels of miR-29a and miR-92a are able to distinguish advanced adenomas and negative controls. ${ }^{53}$ In the research of circulating miR-141 in 102 plasma samples, a significant correlation to colon cancer stage IV was determined. ${ }^{54}$ The accuracy was further improved by combining the levels of miR-141 to carcinoembryonic antigen marker. For more accurate diagnostics, expression levels of several miRNAs should be monitored.
Expression of 47 miRNAs in 101 FFPE samples of primary cancers and metastasis was evaluated, determining the tissue of origin. The identification of tissue was $100 \%$ for primary cancers and $78 \%$ for metastases. The accuracy remained high for independent sample validation. ${ }^{55}$ miRNA expression arrays can be utilized, when the other established clinical tests are inconclusive.

\section{LncRNA diagnostic}

lncRNA is a fast growing field of research and many discovered lncRNA are deregulated in cancer (Table 2).

HOTAIR interacts with polycomb repressor complex PRC2, which causes the transcriptional silencing of several metastasis suppressor genes lo- 
cated in HOXD locus on chromosome 2. ${ }^{56}$ Elevated expression of HOTAIR was observed in primary and metastatic breast cancer compared to normal tissue. The high expression of HOTAIR is also correlated to metastasis and poor survival rate. ${ }^{56}$ HOTAIR can be a potential biomarker for the existence of lymph node metastasis in hepatocelular carcinoma (HCC). ${ }^{57}$

ANRIL activates two polycomb repressor complexes, PRC1 and PRC2, which results in chromatin reorganization, silencing the INK4b-ARFINK4a locus encoding tumor suppressor genes, involved in cell cycle inhibition, and stress-induced apoptosis. Overexpression of ANRIL in prostate cancer has shown silencing of INK4b-ARF-INK4a and $\mathrm{p} 15 / \mathrm{CDKN} 2 \mathrm{~B}$ by heterochromatin reformation. $.88,87$

MALAT1 is widely expressed in normal human tissues and is found to be up-regulated in a variety of human cancers of the breast, prostate, colon, liver and uterus. ${ }^{75,76}$ The MALAT1 locus is located at 11q13.1 and was found to harbour chromosomal translocation break points associated with cancer. ${ }^{88}$ It has been shown that increased expression of MALAT1 can be used as a prognostic marker for HCC patients following liver transplantation. ${ }^{89}$

H19 and the insulin-like growing factor 2 (IGF2) are imprinted, and expressed from the maternal allele, and from parental allele, respectively. ${ }^{62,68}$ The loss of imprinting results in misexpression of H19 and was observed in many tumors including hepatocellular and bladder cancer. ${ }^{64} c-M Y C$ induces the expression of H19 in different cell types where H19 potentiates tumorigenesis. ${ }^{68}$

LncRNA MEG3 is a transcript of the maternally imprinted gene. In normal pituitary cells MEG3 is expressed, the loss of expression is observed in pituitary adenomas and the majority of meningiomas and meningioma cell lines. MEG3 activates regulation of tumor suppressor protein p53.77,78

Growth Arrest-Specific 5 (GAS5) functions as a starvation or growth arrest-linked riborepressor for the glucocorticoid receptors by binding to their DNA binding domain inhibiting the association of these receptors with their DNA recognition sequence. This suppresses the induction of several responsive genes including the gene encoding cellular inhibitor of apoptosis 2 (cIAP2), reducing cell metabolism and synthesizes cells to apoptosis. ${ }^{90}$ GAS5 can induce apoptosis directly or indirectly in the prostate and breast cancer cell lines, where it was shown that GAS5 has a significantly lower expression in breast cancers compared to normal breast epithelial tissues. ${ }^{86}$
One of the lncRNA utilized in a clinical test is prostate cancer associated (PCA3), which is a prostate cancer specific lncRNA. It can be detected in urine samples obtained after a prostatic massage. ${ }^{91,92}$ Studies, comparing the levels of PCA3 to current biomarker prostate specific antigen (PSA), were conducted, showing that PCA3 has higher specificity than PSA, reducing the number of biopsies. Also PCA3 levels correlate better to identification of disease, since PSA levels can be also elevated due to inflammatory reasons. The accuracy was improved when profiling of both PCA3 and PSA in blood was performed..$^{93}$

There are two IncRNA connected to HCC, highly up-regulated in liver cancer (HULC) and HOTAIR. HULC is detected in peripheral blood cells and therefore has a potential as a biomarker. ${ }^{72}$ HOTAIR has also been correlated to HCC and has potential to become a biomarker for lymph node metastasis and tumor recurrence in HCC patients' undergone a liver transplant. ${ }^{57,70}$

Clinical trials on biomarkers are mostly performed on specimens that are easily obtainable, such as blood or urine, and present little discomfort to patients, where on the other hand trials are rare on tumor tissue, due to the specimen unavailability. The detection of early stage disease in body fluids is ideal for patients, due to its non-invasive nature. Still many questions persist, like stability of the circulating molecules, and their stability in the progression of disease. There is also evidence of some specific expression in cancers, but with the on-going research on this topic there will be more evidence of involvement of lncRNA in cancer. ${ }^{71,93}$

\section{Potential of therapy}

After proving many miRNA and lncRNA are deregulated in cancer, the research now focuses on their role as therapeutic targets. ${ }^{94}$

MiRNAs involved and deregulated in cancer are divided into tumor suppressor and oncogenic miRNAs. Oncogenic miRNAs are overexpressed in cancer, downregulating tumor suppressor genes..$^{95}$ To reverse the oncogenic miRNA expression they have to be inhibited to relieve their targets. This can be achieved by introducing mRNAs targeting specific miRNAs or by using antisense single-stranded oligonucleotides complementary to miRNA, acting as miRNA sponges and miRNA antagonists, respectively. ${ }^{96-98}$ On the other hand tumor suppressor miRNAs are under expressed in the cancer, their role being down-regulation of oncogenes. ${ }^{95,99}$ To 
restore the levels of tumor suppressor miRNAs the replacement therapy of mimics miRNA or DNA coding for specific miRNAs is needed. ${ }^{96,100}$ This is schematically presented in Figure 2.

Inhibition of oncogenic miRNAs has been widely researched through siRNA-based therapeutic modalities, and antisense oligonucleotides, which have been a straightforward approach relieving repressed targets of miRNA. ${ }^{101,102}$ Antisense oligonucleotides can be designed to potentially block several steps during the biogenesis and action of miRNA, miRNA processing or miRNA pairing with targeted mRNA. In vitro and in vivo mice studies used modified antisense oligonucleotides to inhibit tumor proliferation, migration, invasion, and apoptosis. ${ }^{96}$ Antisense oligonucleotide targeting miR-21 in in vitro and in vivo xenograft model resulted in the inhibition of breast cancer cell growth, inhibited cell proliferation, and increased apoptosis. ${ }^{103}$ Besides antisense oligonucleotide inhibition, miRNA sponges as another technique to effectively lower the levels of miRNA has been used, where targeted sequence is cloned in multiple copies, and upon transfection into a tumor cell should act as a sponge for the miRNA and relieve its natural target. ${ }^{104}$ In breast cancer cell lines, a miRNA sponge trapping up-regulated miR-9 connected to cancer metastasis effectively reduced invasiveness of the tumor cells. ${ }^{105}$

The replacement therapy for down-regulated tumor suppressor miRNA is administration of synthetic miRNA. Tumor suppressor let-7 miRNA, known to be associated with many tumors, was delivered intratumorally in a mouse model of nonsmall-cell lung cancer, which led to reduction of tumor burden. ${ }^{106}$ Several studies suggest that let-7 acts through direct repression of KRAS and $c-M Y C$ oncogenes. ${ }^{107}$ Another deregulated miRNA associated with several cancers is miR-34. Through transfection or lentiviral-mediated delivery of mimic miR-34 to cancer cells, the cell-cycle arrest, apoptosis and reduction in tumor size was observed. ${ }^{108}$

It is observed, in both EU and US, a large increase of patents connected to miRNA. Many miRNA based therapeutics is either in preclinical or clinical trial phase. In cancer treatment Mirna Therapeutics has developed miRNA mimic therapeutics for miR-34 (phase I) and let-7 (preclinical).

While many targeting strategies are implied to reverse the levels of miRNA, for lncRNA these strategies are still being developed. In principle the same strategies as for miRNA could be used, like introducing molecules designed to target lncRNA to lower the expression levels or disrupt the lncRNA in structural or functional way.

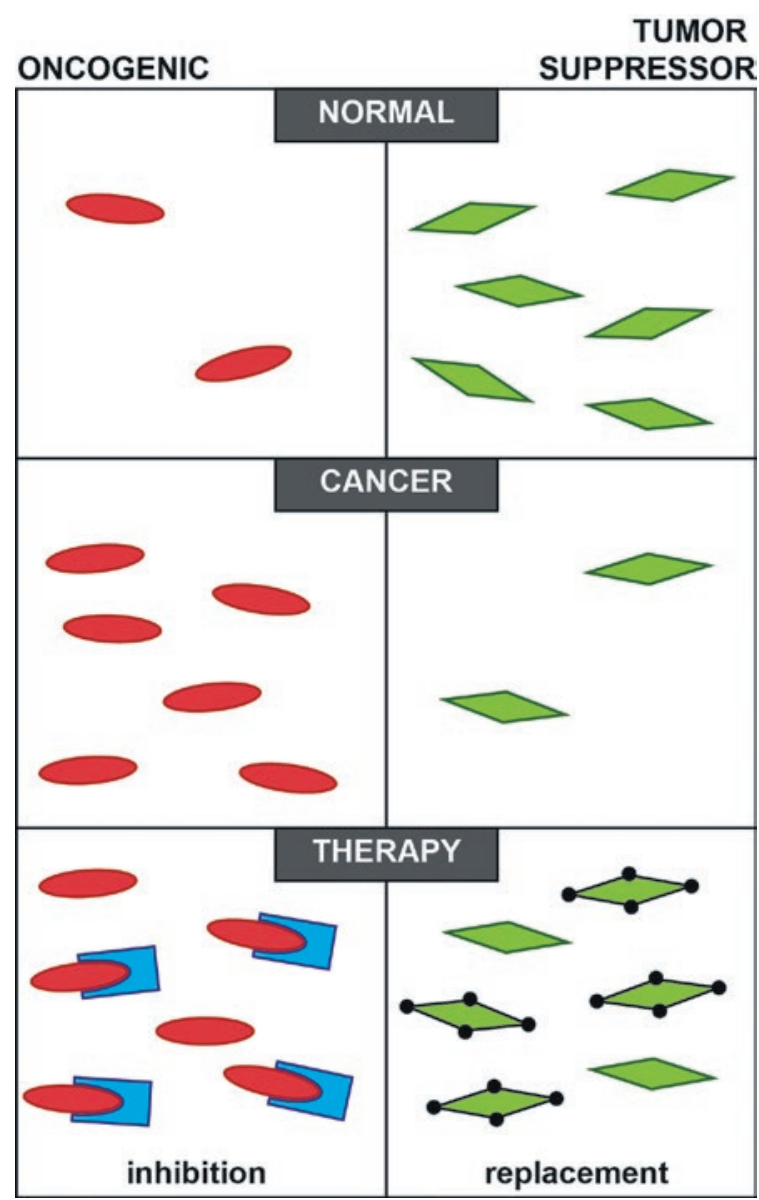

FIGURE 2. Schematic presentation of oncogenic and tumor suppressor miRNAs in normal and cancer cell and the potential of modifying state in cancer cell with therapy.

There is evidence that the expression can be lowered through RNAi technology, degradation by RnaseH or by genomic integration of RNA destabilizing elements. ${ }^{109}$ Modifying the expression levels can represent some difficulty due to possible secondary structure of lncRNA. Inactivation of lncRNA is also possible through inhibition of active site via small molecule inhibitors. To be able to do this the molecular function needs to be known, which for most lncRNA is still elusive. It is also possible to disrupt the structure of lncRNA. Due to their length it is presumed some secondary structures exist. With the use of specially designed small molecules this structures would be disrupted leading to lncRNA loss of function. The potential of using specific therapeutics that would enable the mimicking or inhibition of certain non-coding RNA is promising and enormous. ${ }^{110}$

To reverse the levels of disrupted lncRNA in cancer a replacement therapy is also an option. 
Some strategies of delivery are being explored. The use of IncRNA H19 specific expression in tumors has been explored through a plasmid delivery. Intratumoral delivery of plasmid, which carries the gene for the A subunit of diphtheria toxin under the regulation of H19 promoter, induces high expression of diphtheria toxin, which results in reduced tumor size. ${ }^{111}$

\section{Conclusions}

Studies of miRNA and IncRNA have highlighted the importance of non-coding part of human genome. Of all lncRNA only few have been well characterized. Research also shows they have important function in cancer initiation, progression and metastasis. Further expression patterns in cancer will improve diagnosis and prognosis of cancer. With more functional and structural studies the potential of lncRNA therapies will be seen.

MiRNA as regulators of multiple genes promise a great potential in therapeutics and a switch from one drug one target to one drug multiple target therapy. Although there were great advances made in replacement and inhibitory strategies there are still challenges that include stability, safety and delivery of the chosen therapeutics. For therapeutics to become a successful application, the drug needs to be delivered in a way that ensures the stability of the molecules' transport to the appropriate cells.

\section{References}

1. Iorio MV, Croce CM. MicroRNA dysregulation in cancer: diagnostics, monitoring and therapeutics. A comprehensive review. EMBO Mol Med 2012; 4: 143-59.

2. Mattick JS. The Genetic Signatures of Noncoding RNAs. PLoS Genet 2009;

3. Eddy SR. Non-coding RNA genes and the modern RNA world. Nat Rev Genet 2001; 2: 919-29.

4. Mercer TR, Dinger ME, Mattick JS. Long non-coding RNAs: insights into functions. Nat Rev Genet 2009; 10: 155-9.

5. Kapranov P, Drenkow J, Cheng J, Long J, Helt G, Dike S, et al. Examples of the complex architecture of the human transcriptome revealed by RACE and high-density tiling arrays. Genome Res 2005; 15: 987-97.

6. Sana J, Faltejskova P, Svoboda M, Slaby O. Novel classes of non-coding RNAs and cancer. J Transl Med 2012; 10: 103.

7. Zen K, Zhang CY. Circulating MicroRNAs: a novel class of biomarkers to diagnose and monitor human cancers. Med Res Rev 2012; 32: 326-48.

8. Taft RJ, Pang KC, Mercer TR, Dinger M, Mattick JS. Non-coding RNAs: regulators of disease. J Pathol 2010; 220: 126-39.

9. Cortez MA, Bueso-Ramos C, Ferdin J, Lopez-Berestein G, Sood AK, Calin GA MicroRNAs in body fluids-the mix of hormones and biomarkers. Nat Rev Clin Oncol 2011; 8: 467-77.
10. Rinn JL, Chang HY. Genome regulation by long noncoding RNAs. Annu Rev Biochem 2012; 81: 145-66.

11. Siomi MC, Sato K, Pezic D, Aravin AA. PIWI-interacting small RNAs: the vanguard of genome defence. Nat Rev Mol Cell Bio 2011; 12: 246-58.

12. Williams GT, Farzaneh F. Are snoRNAs and snoRNA host genes new players in cancer? Nat Rev Cancer 2012; 12: 84-8.

13. Montanaro L, Trere D, Derenzini M. Nucleolus, ribosomes, and cancer. Am J Pathol 2008; 173: 301-10.

14. Lares MR, Rossi JJ, Ouellet DL. RNAi and small interfering RNAs in human disease therapeutic applications. Trends Biotechnol 2010; 28: 570-9.

15. Mesojednik S, Kamensek U, Cemazar M. Evaluation of shRNA-mediated gene silencing by electroporation in LPB fibrosarcoma cells. Radiol Oncol 2008; 42: 82-92.

16. Wu XY, Zhong DX, Lin B, Zhai WL, Ding ZQ, Wu J. p38 MAPK regulates the expression of ether a go-go potassium channel in human osteosarcoma cells. Radiol Oncol 2013; 47: 42-9.

17. Zhao SH, Zhao F, Zheng JY, Gao LF, Zhao XJ, Cui MH. Knockdown of stat 3 expression by RNAi inhibits in vitro growth of human ovarian cancer. Radiol Oncol 2011; 45: 196-203.

18. Hui A, How C, Ito E, Liu FF. Micro-RNAs as diagnostic or prognostic markers in human epithelial malignancies. BMC Cancer 2011; 11: 500.

19. Bustin SA, Murphy J. RNA biomarkers in colorectal cancer. Methods 2013; 59: 116-25.

20. Bresters D, Schipper MEI, Reesink HW, Boesernunnink BDM, Cuypers HTM. The Duration of Fixation Influences the Yield of Hcv Cdna-Pcr Products from Formalin-Fixed, Paraffin-Embedded Liver-Tissue. J Virol Methods 1994; 48: 267-72.

21. Cronin M, Pho M, Dutta D, Stephans JC, Shak S, Kiefer MC, et al. Measurement of gene expression in archival paraffin-embedded tissues: development and performance of a 92-gene reverse transcriptase-polymerase chain reaction assay. Am J Pathol 2004; 164: 35-42.

22. Nelson PT, Baldwin DA, Scearce LM, Oberholtzer JC, Tobias JW, Mourelatos Z. Microarray-based, high-throughput gene expression profiling of microRNAs. Nature Methods 2004; 1: 155-61.

23. Hui AB, Shi W, Boutros PC, Miller N, Pintilie M, Fyles T, et al. Robust global micro-RNA profiling with formalin-fixed paraffin-embedded breast cancer tissues. Lab Invest 2009; 89: 597-606.

24. Lu Z, Liu M, Stribinskis V, Klinge CM, Ramos KS, Colburn NH, et al MicroRNA-21 promotes cell transformation by targeting the programmed cell death 4 gene. Oncogene 2008; 27: 4373-9.

25. Asangani IA, Rasheed SAK, Nikolova DA, Leupold JH, Colburn NH, Post S, et al. MicroRNA-21 (miR-21) post-transcriptionally downregulates tumor suppressor Pdcd4 and stimulates invasion, intravasation and metastasis in colorectal cancer. Oncogene 2008; 27: 2128-36.

26. Sempere LF, Christensen M, Silahtaroglu A, Bak M, Heath CV, Schwart $\mathrm{G}$, et al. Altered microRNA expression confined to specific epithelial cell Subpopulations in breast cancer. Cancer Res 2007; 67: 11612-20.

27. Roth C, Rack B, Muller V, Janni W, Pantel K, Schwarzenbach H. Circulating microRNAs as blood-based markers for patients with primary and metastatic breast cancer. Breast Cancer Res 2010; 12: R90.

28. Wang FJ, Zheng ZG, Guo JF, Ding XF. Correlation and quantitation of microRNA aberrant expression in tissues and sera from patients with breast tumor. Gynecol Oncol 2010; 119: 586-93.

29. Heneghan HM, Miller N, Kelly R, Newell J, Kerin MJ. Systemic miRNA-195 Differentiates Breast Cancer from Other Malignancies and Is a Potentia Biomarker for Detecting Noninvasive and Early Stage Disease. Oncologist 2010; 15: 673-82.

30. Lebanony D, Benjamin H, Gilad S, Ezagouri M, Dov A, Ashkenazi K, et al. Diagnostic Assay Based on hsa-miR-205 Expression Distinguishes Squamous From Nonsquamous Non-Small-Cell Lung Carcinoma. J Clin Oncol 2009; 27: 2030-7.

31. Roth C, Kasimir-Bauer S, Pantel K, Schwarzenbach H. Screening for circulating nucleic acids and caspase activity in the peripheral blood as potential diagnostic tools in lung cancer. Mol Oncol 2011; 5: 281-91. 
32. Xiao BX, Guo JM, Miao Y, Jiang Z, Huan R, Zhang YY, et al. Detection of miR106a in gastric carcinoma and its clinical significance. Clin Chim Acta 2009; 400: 97-102.

33. Zhang YY, Guo JM, Li D, Xiao BX, Miao Y, Jiang Z, et al. Down-regulation of miR-31 expression in gastric cancer tissues and its clinical significance. Med Oncol 2010; 27: 685-9.

34. Zhang CN, Wang C, Chen X, Yang CH, Li K, Wang JJ, et al. Expression Profile of MicroRNAs in Serum: A Fingerprint for Esophageal Squamous Cell Carcinoma. Clin Chem 2010; 56: 1871-9.

35. Liu R, Zhang CN, Hu ZB, Li G, Wang C, Yang $\mathrm{CH}$, et al. A five-microRNA signature identified from genome-wide serum microRNA expression profiling serves as a fingerprint for gastric cancer diagnosis. Eur J Cancer 2011; 47: 784-91.

36. Bloomston $M$, Frankel WL, Petrocca F, Volinia S, Alder H, Hagan JP, et al. MicroRNA expression patterns to differentiate pancreatic adenocarcinoma from normal pancreas and chronic pancreatitis. Jama-J Am Med Assoc 2007; 297: 1901-8.

37. Habbe N, Koorstra JBM, Mendell JT, Offerhaus GJ, Ryu JK, Feldmann G, et al. MicroRNA miR-155 is a biomarker of early pancreatic neoplasia. Cancer Biol Ther 2009; 8: 340-6.

38. du Rieu MC, Torrisani J, Selves J, Al Saati T, Souque A, Dufresne M, et al. MicroRNA-21 Is Induced Early in Pancreatic Ductal Adenocarcinoma Precursor Lesions. Clin Chem 2010; 56: 603-12.

39. Kong $X Y, D u Y Q$, Wang GK, Gao J, Gong YF, Li L, et al. Detection of Differentially Expressed microRNAs in Serum of Pancreatic Ductal Adenocarcinoma Patients: miR-196a Could Be a Potential Marker for Poor Prognosis. Dig Dis Sci 2011; 56: 602-9.

40. Ho AS, Huang X, Cao HB, Christman-Skieller C, Bennewith K, Le QT, et al. Circulating miR-210 as a Novel Hypoxia Marker in Pancreatic Cancer. Transl Oncol 2010; 3: 109-13.

41. Wang J, Chen JY, Chang P, LeBlanc A, Li DH, Abbruzzesse JL, et al. MicroRNAs in Plasma of Pancreatic Ductal Adenocarcinoma Patients as Novel Blood-Based Biomarkers of Disease. Cancer Prev Res 2009; 2: 80713.

42. Shi XB, Xue L, Yang J, Ma AH, Zhao J, Xu M, et al. An androgen-regulated miRNA suppresses Bak1 expression and induces androgen-independent growth of prostate cancer cells. Proc Natl Acad Sci U S A 2007; 104: 199838.

43. Bonci D, Coppola V, Musumeci M, Addario A, Giuffrida R, Memeo L, et al. The miR-15a-miR-16-1 cluster controls prostate cancer by targeting multiple oncogenic activities. Nat Med 2008; 14: 1271-7.

44. Saini S, Majid S, Yamamura S, Tabatabai L, Suh SO, Shahryari V, et al. Regulatory Role of mir-203 in Prostate Cancer Progression and Metastasis. Clin Cancer Res 2011; 17: 5287-98.

45. Hagman Z, Larne O, Edsjo A, Bjartell A, Ehrnstrom RA, Ulmert D, et al. miR-34c is downregulated in prostate cancer and exerts tumor suppressive functions. Int J Cancer 2010; 127: 2768-76.

46. Spahn M, Kneitz S, Scholz $\mathrm{CJ}$, Stenger $\mathrm{N}$, Rudiger $\mathrm{T}$, Strobel $\mathrm{P}$, et al. Expression of microRNA-221 is progressively reduced in aggressive prostate cancer and metastasis and predicts clinical recurrence. Int J Cancer 2010; 127: 394-403.

47. Mitchell PS, Parkin RK, Kroh EM, Fritz BR, Wyman SK, Pogosova-Agadjanyan EL, et al. Circulating microRNAs as stable blood-based markers for cancer detection. Proc Natl Acad Sci U S A 2008; 105: 10513-8.

48. Brase $J C$, Johannes $M$, Schlomm $T$, Falth $M$, Haese $A$, Steuber $T$, et at. Circulating miRNAs are correlated with tumor progression in prostate cancer. Int J Cancer 2011; 128: 608-16.

49. Zhang HL, Yang LF, Zhu Y, Yao XD, Zhang SL, Dai B, et al. Serum miRNA-21: Elevated Levels in Patients With Metastatic Hormone-Refractory Prostate Cancer and Potential Predictive Factor for the Efficacy of Docetaxel-Based Chemotherapy. Prostate 2011; 71: 326-31.

50. Agaoglu FY, Kovancilar M, Dizdar Y, Darendeliler E, Holdenrieder S, Dalay N, et al. Investigation of miR-21, miR-141, and miR-221 in blood circulation of patients with prostate cancer. Tumor Biology 2011; 32: 583-8.

51. Bryant RJ, Pawlowski T, Catto JWF, Marsden G, Vessella RL, Rhees B, et al. Changes in circulating microRNA levels associated with prostate cancer. $\mathrm{Br}$ J Cancer 2012; 106: 768-74.
52. Kluiver J, Poppema S, de Jong D, Blokzijl T, Harms G, Jacobs S, et al. BIC and miR-155 are highly expressed in Hodgkin, primary mediastinal and diffuse large B cell lymphomas. J Pathol 2005; 207: 243-9.

53. Huang ZH, Huang D, Ni SJA, Peng ZL, Sheng WQ, Du X. Plasma microRNAs are promising novel biomarkers for early detection of colorectal cancer. Int J Cancer 2010; 127: 118-26.

54. Cheng HY, Zhang LN, Cogdell DE, Zheng H, Schetter AJ, Nykter M, et al. Circulating Plasma MiR-141 Is a Novel Biomarker for Metastatic Colon Cancer and Predicts Poor Prognosis. PLoS One 2011; 6: e17745.

55. Ferracin M, Pedriali M, Veronese A, Zagatti B, Gafa R, Magri E, et al. MicroRNA profiling for the identification of cancers with unknown primary tissue-of-origin. J Pathol 2011; 225: 43-53.

56. Gupta RA, Shah N, Wang KC, Kim J, Horlings HM, Wong DJ, et al. Long non-coding RNA HOTAIR reprograms chromatin state to promote cancer metastasis. Nature 2010; 464: 1071-6.

57. Geng YJ, Xie SL, Li Q, Ma J, Wang GY. Large Intervening Non-coding RNA HOTAIR is Associated with Hepatocellular Carcinoma Progression. J Int Med Res 2011; 39: 2119 - 28.

58. Yu W, Gius D, Onyango P, Muldoon-Jacobs K, Karp J, Feinberg AP, et al. Epigenetic silencing of tumour suppressor gene p15 by its antisense RNA. Nature 2008; 451: 202-6.

59. Chen W, Böcker W, Brosius J, Tiedge H. Expression of neural BC200 RNA in human tumours. J Pathol 1997; 183: 345-51.

60. lacoangeli A, Lin Y, Morley EJ, Muslimov IA, Bianchi R, Reilly J, et al. BC200 RNA in invasive and preinvasive breast cancer. Carcinogenesis 2004; 25: 2125-33.

61. Chung S, Nakagawa H, Uemura M, Piao L, Ashikawa K, Hosono N, et al. Association of a novel long non-coding RNA in 8q24 with prostate cance susceptibility. Cancer Sci 2011; 102: 245-52.

62. Gabory A, Jammes H, Dandolo L. The $\mathrm{H} 19$ locus: role of an imprinted noncoding RNA in growth and development. Bioessays 2010; 32: 473-80.

63. Hibi K, Nakamura H, Hirai A, al. e. Loss of H19 imprinting in esophageal cancer. Cancer Res 1996; 56: 480-2.

64. Fellig $\mathrm{Y}$, Ariel I, Ohana $\mathrm{P}$, Schachter $\mathrm{P}$, Sinelnikov I, Birman T, et al. $\mathrm{H} 19$ expression in hepatic metastases from a range of human carcinomas. $J$ Clin Pathol 2005; 58: 1064-8.

65. Matouk IJ, DeGroot N, Mezan S, Ayesh S, Abu-lail R, Hochberg A, et al. The $\mathrm{H} 19$ non-coding RNA is essential for human tumor growth. PLoS One 2007; 2: e845.

66. Arima T, Matsuda T, Takagi N, Wake N. Association of IGF2 and H19 imprinting with choriocarcinoma development. Cancer Genet Cytogenet 1997; 93: 39-47.

67. Berteaux N, Lottin S, Monte D, Pinte S, Quatannens B, Coll J, et al. H19 mRNA-like noncoding RNA promotes breast cancer cell proliferation through positive control by E2F1. J Biol Chem 2005; 280: 29625-36.

68. Barsyte-Lovejoy D, Lau SK, Boutros PC, Khosravi F, Jurisica I, Andrulis IL, et al. The c-Myc oncogene directly induces the H19 noncoding RNA by allelespecific binding to potentiate tumorigenesis. Cancer Res 2006; 66: 5330-7.

69. Tsai MC, Manor O, Wan Y, Mosammaparast N, Wang JK, Lan F, et al. Long noncoding RNA as modular scaffold of histone modification complexes. Science 2010; 329: 689-93.

70. Yang Z, Zhou L, Wu LM, Lai MC, Xie HY, Zhang F, et al. Overexpression of long non-coding RNA HOTAIR predicts tumor recurrence in hepatocellula carcinoma patients following liver transplantation. Ann Surg Oncol 2011; 18: $1243-50$.

71. Matouk IJ, Abbasi I, Hochberg A, Galun E, Dweik H, Akkawi M. Highly upregulated in liver cancer noncoding RNA is overexpressed in hepatic colorectal metastasis. Eur J Gastroenterol Hepatol 2009; 21: 688-92.

72. Panzitt K, Tschernatsch MM, Guelly C, Moustafa T, Stradner M, Strohmaier $\mathrm{HM}$, et al. Characterization of HULC, a novel gene with striking up-regulation in hepatocellular carcinoma, as noncoding RNA. Gastroenterology 2007; 132: 330-42.

73. Guffanti A, lacono M, Pelucchi P, Kim N, Solda G, Croft $\sqcup$, et al. A transcriptional sketch of a primary human breast cancer by 454 deep sequencing. BMC Genomics 2009; 10: 163. 
74. Yamada K, Kano J, Tsunoda H, Yoshikawa H, Okubo C, Ishiyama T, et al. Phenotypic characterization of endometrial stromal sarcoma of the uterus. Cancer Sci 2006; 97: 106-12.

75. Lin R, Maeda S, Liu C, Karin M, Edgington TS. A large noncoding RNA is a marker for murine hepatocellular carcinomas and a spectrum of human carcinomas. Oncogene 2007; 26: 851-8.

76. Luo JH, Ren B, Keryanov S, Tsang GC, Reo UNM, Monga SP, et al. Transcriptomic and genomic analysis of human hepatocellular carcinomas and hepatoblastomas. Hepatology 2006; 44: 1012-24.

77. Gejman R, Batista DL, Zhong $Y$, Zhou $Y$, Zhang $X$, Swearingen $B$, et al. Selective loss of MEG3 expression and intergenic differentially methylated region hypermethylation in the MEG3/DLK1 locus in human clinically nonfunctioning pituitary adenomas. J Clin Endocrinol Metab 2008; 93: 411925.

78. Benetatos L, Vartholomatos G, Hatzimichael E. MEG3 imprinted gene contribution in tumorigenesis. Int J Cancer 2011; 129: 773-9.

79. Poliseno L, Salmena L, Zhang J, Carver B, Haveman WJ, Pandolfi PP. A coding-independent function of gene and pseudogene mRNAs regulates tumour biology. Nature 2010; 465: 1033-8.

80. Khaitan D, Dinger ME, Mazar J, Crawford J, Smith MA, Mattick JS, et al. The melanoma-upregulated long noncoding RNA SPRY4-IT1 modulates apoptosis and invasion. Cancer Res 2011; 71: 3852-62.

81. Lanz RB, Chua SS, Barron N, Soder BM, DeMayo F, O'Malley BW. Steroid Receptor RNA Activator Stimulates Proliferation as Well as Apoptosis In Vivo. Mol Cell Biol 2003; 23: 7163-76.

82. Chooniedass-Kothari S, Vincett D, Yan Y, Cooper C, Hamedani MK, Myal Y, et al. The protein encoded by the functional steroid receptor RNA activator is a new modulator of ER alpha transcriptional activity. FEBS Lett 2010; 584: $1174-80$

83. Wang F, Li X, Xie X, Zhao L, Chen W. UCA1, a non-protein-coding RNA upregulated in bladder carcinoma and embryo, influencing cell growth and promoting invasion. FEBS Lett 2008; 582: 1919-27.

84. Wang XS, Zhang Z, Wang HC, Cai JL, Xu QW, Li MQ, et al. Rapid identification of UCA1 as a very sensitive and specific unique marker for human bladder carcinoma. Clin Cancer Res 2006; 12: 4851-8.

85. de Kok JB, Verhaegh GW, Roelofs RW, Hessels D, Kiemeney LA, Aalders TW et al. DD3(PCA3), a very sensitive and specific marker to detect prostate tumors. Cancer Res 2002; 62: 2695-89.

86. Mourtada-Maarabouni M, Pickard MR, Hedge VL, Farzaneh F, Williams GT. GAS5, a non-protein-coding RNA, controls apoptosis and is downregulated in breast cancer. Oncogene 2009; 28: 195-208.

87. Yap KL, Li S, Munoz-Cabello AM, Raguz S, Zeng L, Mujtaba S, et al. Molecular interplay of the noncoding RNA ANRIL and methylated histone $\mathrm{H} 3$ lysine 27 by polycomb CBX7 in transcriptional silencing of INK4a. Mol Cell 2010; 38: 662-74.

88. Rajaram V, Knezevich S, Bove KE, Perry A, Pfeifer JD. DNA sequence of the translocation breakpoints in undifferentiated embryonal sarcoma arisin in mesenchymal hamartoma of the liver harboring the $t(11 ; 19)(q 11 ; q 13.4)$ translocation. Genes Chromosom Cancer 2007; 46: 508-13.

89. Lai MC, Yang Z, Zhou L, Zhu QQ, Xie HY, Zhang F, et al. Long non-coding RNA MALAT-1 overexpression predicts tumor recurrence of hepatocellular carcinoma after liver transplantation. Med Oncol 2012; 29: 1810-6.

90. Kino T, Hurt DE, Ichijo T, Nader N, Chrousos GP. Noncoding RNA gas5 is a growth arrest- and starvation-associated repressor of the glucocorticoid receptor. Sci Signal 2010; 3: ra8.

91. Marks LS, Fradet Y, Deras IL, Blase A, Mathis J, Aubin SMJ, et al. PCA3 molecular urine assay for prostate cancer in men undergoing repeat biopsy. Urology 2007; 69: 532-5.

92. Tinzl M, Marberger M, Horvath S, Chypre C. DD3PCA3 RNA Analysis in Urine - a new perspective for detecting prostate cancer. Eur Urol 2004; 46 182-7.

93. Neves AF, Dias-Oliveira JDD, Araujo TG, Marangoni K, Goulart LR. Prostate cancer antigen 3 (PCA3) RNA detection in blood and tissue samples fo prostate cancer diagnosis. Clin Chem Lab Med 2013; 51: 881-7.

94. Oberg AL, French AJ, Sarver AL, Subramanian S, Morlan BW, Riska SM, et al. miRNA Expression in Colon Polyps Provides Evidence for a Multihit Model of Colon Cancer. PLoS One 2011; 6: e20465.
95. Kent OA, Mendell JT. A small piece in the cancer puzzle: microRNAs as tumor suppressors and oncogenes. Oncogene 2006; 25: 6188-96.

96. Kota SK, Balasubramanian S. Cancer therapy via modulation of micro RNA levels: a promising future. Drug Discov Today 2010; 15: 733-40.

97. Bader AG, Brown D, Stoudemire J, Lammers P. Developing therapeutic microRNAs for cancer. Gene Ther 2011; 18: 1121-6.

98. Broderick JA, Zamore PD. MicroRNA therapeutics. Gene Ther 2011; 18 1104-10.

99. Croce $\mathrm{CM}$. Causes and consequences of microRNA dysregulation in cancer. Nat Rev Genet 2009; 10: 704-14.

100. Bader AG, Brown D, Winkler M. The Promise of MicroRNA Replacement Therapy. Cancer Res 2010; 70: 7027-30.

101. Dolinsek T, Markelc B, Sersa G, Coer A, Stimac M, Lavrencak J, et al. Multiple Delivery of siRNA against Endoglin into Murine Mammary Adenocarcinoma Prevents Angiogenesis and Delays Tumor Growth. PLoS One 2013; 8: e58723.

102. Todorovic V, Sersa G, Cemazar M. Gene electrotransfer of siRNAs against CD146 inhibits migration and invasion of human malignant melanoma cells SK-MEL28. Cancer Gene Ther 2013; 20: 208-10.

103. Si ML, Zhu S, Wu H, Lu Z, Wu F, Mo YY. miR-21-mediated tumor growth. Oncogene 2007; 26: 2799-803.

104. Ebert MS, Neilson JR, Sharp PA. MicroRNA sponges: competitive inhibitors of small RNAs in mammalian cells. Nature Methods 2007; 4: 721-6.

105. Ma L, Young J, Prabhala H, Pan E, Mestdagh P, Muth D, et al. miR-9, a MYC/ MYCN-activated microRNA, regulates E-cadherin and cancer metastasis. Nat Cell Biol 2010; 12: 247-52.

106. Trang P, Medina PP, Wiggins JF, Ruffino L, Kelnar K, Omotola M, et al. Regression of murine lung tumors by the let-7 microRNA. Oncogene 2010; 29: $1580-7$

107. Kumar MS, Erkeland SJ, Pester RE, Chen CY, Ebert MS, Sharp PA, et al. Suppression of non-small cell lung tumor development by the let-7 microRNA family. Proc Natl Acad Sci U S A 2008; 105: 3903-8.

108. Ji Q, Hao X, Meng Y, Zhang M, DeSano J, Fan DM, et al. Restoration of tumor suppressor miR-34 inhibits human p53-mutant gastric cancer tumorspheres. BMC Cancer 2008; 8: 266.

109. Gutschner T, Baas M, Diederichs S. Noncoding RNA gene silencing through genomic integration of RNA destabilizing elements using zinc finger nucleases. Genome Res 2011; 21: 1944-54.

110. Borralho PM, Simoes AES, Gomes SE, Lima RT, Carvalho T, Ferreira DMS, et al. miR-143 Overexpression Impairs Growth of Human Colon Carcinoma Xenografts in Mice with Induction of Apoptosis and Inhibition of Proliferation. PLoS One 2011; 6: e23787.

111. Mizrahi A, Czerniak A, Levy T, Amiur S, Gallula J, Matouk I, et al. Development of targeted therapy for ovarian cancer mediated by a plasmid expressing diphtheria toxin under the control of $\mathrm{H} 19$ regulatory sequences. J Transl Med 2009; 7: 69. 